\title{
Sexotic: The Interplay between Sexualization and Exoticization
}

Edited by Ulrike Schaper, Magdalena Beljan, Pascal Eitler, Christopher Ewing, Benno Gammerl

Sun, sand and sex. This triad seems to epitomize the promise of the tourist industry that capitalizes on sexotic fantasies. It suggests that exotic surroundings enable experiences out of the ordinary and elicit intensified sensations. The latent sexual promise of exotic surroundings can appeal to couples in search of romance and a boost in sexual satisfaction as well as to people looking for anything from a holiday flirtation to a visit to a cheap brothel in the anonymity and liminality of the tourist space. ${ }^{1}$ A whole branch of the tourist industry is organized around (commercial) sex. Complex power relations pervade such encounters; they touch upon intersecting hierarchies organized along categories such as gender, race, class, origin, age, sexual orientation, wealth and raise questions of agency, exploitation and dependencies that can unfold in various dynamics in the different situations.

Ulrich Seidl's movie Paradies Liebe (2012) about a white middle-aged woman's holiday in Kenya and her depicted quest for sex, appreciation and affection is one recent artistic exploration of some of the complicated ethical issues surrounding sexual encounters in tourist settings. The white woman's sexoticization and objectification of the 'beach boys" black bodies and her unscrupulous deployment of her relative economic power is as distressing as her loneliness and discomfort caused by a society that casts aside older, corpulent women as sexual partners. The saved up holiday to the promised land, where her body still harbors (sexual) attraction (albeit as a marker of her economic position) is her attempted escape, which seems to satisfy only her need for sex but not her overarching need for emotional intimacy. Because the film places a white woman in the center of the narration, it establishes a complicated power dynamic, since economic, racialized and gendered hierarchies are not aligned. It reminds us that processes of exoticization and sexualization unfold in contexts structured by economic and political inequalities. The film invokes, contradicts and overturns a long tradition of ('Western') men that used sexual encounters with women (but also with younger men and boys) of foreign countries in order to conquest foreign lands.

The sexual as well as the exotic are prominent markers of the unknown, of alterity, and of 'excess' in the 'Western' imaginary (cf. e.g. Eder, 2009; Foucault, 1978). ${ }^{2}$ These different dimensions of unfamiliarity often mutually intensify each other (Yegenoglu, 1998; Bitterli, 1991; Said, 2003). Yet, sexual encounters with inhabitants of foreign places have also been used or idealized as a primary way to know the unknown, to participate in a different culture and have thus generally become part of the fascination the exotic other holds for many (Littlewood, 2002).

With the term 'sexotic', we point to the intersection between processes of sexualization and exoticization. We thus foreground processes of exoticization that build on alleged differences in the sexual drive, attitudes towards sexuality and sexual behavior, which construct them as the origin and determinant of the exotic quality. At the same time, we place special emphasis on processes of sexualization that constructs the 'exotic' as sexually attractive, desirable and stimulating. This dimension of sexoticization entails, for example, the sexual fetishization of a certain skin colour or images of the beach as a space that facilitates passionate sex. The term sexotic thus serves to expose the sexual quality commonly associated with the exotic and the exotic quality associated with sex. 
We understand the sexotic as a strictly relational category that is applied to express the polyvalent relation towards places, people, objects and practices that marks them as fascinating and desirable yet simultaneously different and often threatening. In this understanding no inherent feature serves as a disposition for being sexotic. Who or what is sexotic lies in the eye of the beholder and can choose race, origin, nationality or ethnicity as well as class, religion or sexual orientation as a starting point for exoticization processes. In addition, the dynamics of sexoticization can unfold discriminatory, idealizing, emancipatory or normalizing registers. We conceptualize sexoticization as constituting a positive sense of self by simultaneously dismissing the other as inferior or - more neutrally - as simply different. Thereby, the dissociation of or from the sexoticized other and the creation of hierarchies are crucial, while the sexoticized can at the same time be the source of fascination, (sexual) longing or critiquing one's own 'culture'.

The emphasis on relationality allows us to delineate for each individual case how the sexotic was constructed, and which features were marked as sexotic. This relational understanding can for example be useful when regarding how from a U.S. standpoint Europe was constructed as a sexotic space, thus breaking with common notions of the sexotic being the non-European other. ${ }^{3}$ Processes of sexoticization can also unfold outside the European tradition as Saheed Aderinto (2015: 105-106) shows when illustrating how 'sexual exoticism' contributed to transnational migration of sex workers between Nigeria and the Gold Coast. While the term exotic in the material under examination indicates and produces asymmetrical power relations, the sexotic as an analytical category serves as a tool to identify interwoven processes of othering that are inherently connected to sex, desire and sexual fantasy. References to the exotic can be questioned in respect to how they construct people, objects, spaces or practices as exotic and as sexual both simultaneously and in relation to each other. Who is described and depicted in colonial and postcolonial contexts as sexually active or passive, seductive, desirable or sexually attractive? Which political effects do such attributions produce? How do different dimensions of discrimination intersect in such instances? How are different societal or regional groups hierarchized in respect to their (s)exoticism and how does this transform their scopes to maneuver these images?

This emphasis on relationality makes the 'sexotic' - on a methodological level - a marker devoid of content. It thus differs from other concepts that were created to point to specific intersections of othering and sexualization. McClintock's pornotropics - a European imaginary realm onto which sexual desires and fears were projected and which in the nineteenth century was primarily located in Africa - could be understood as one specific albeit historically important and frequent formation of the sexotic (McClintock, 1995: 21-24). Nevertheless, Europeans share a long tradition of longings for the primordial, unspoiled and uninhibited sexuality of supposedly uncivilized others that expose the contradictions and the ambivalences of the Western civilizing project in interesting ways (Hyam, 1990; McClintock, 1995; Schülting, 1997; Stoler, 1995). Therefore empirically, European references to a non-European sexotic other also feature prominently in our collection (Fludernik, 2002). While the term 'othering' focuses on the powerladen aspect of constructing difference the term 'sexotic' - that builds on the ambivalent term of the exotic - also allows for analyses of how the sexoticised others shaped processes of sexoticization, how they appropriated images which were projected on them, and how they could 
use the implicit seduction for their own benefits - without denying the power asymmetries and constraints in which these processes took place or the implicit hierarchies they produced.

\section{Intersectionality and Body Techniques: Conceptual Vistas for Exploring the Sexotic}

We hold that this multifaceted field of sexotic encounters and practices can best be charted by focusing on the interplay between different socially construed categories like race, class, gender and sexual orientation and the discriminatory effects their interactions engender, thus highlighting the approaches of intersectionality and assemblage theory (McCall, 2005: 1771-1800; Puar, 2011; on the relationship between sexuality and race, see Nagel, 2003: 200-224; on intersectionality, see also Puar, 2007). It is important to analyze how the sexotic is linked to various social categories and how their interaction and cross identification engender distinct effects. In this respect it is interesting to know, for example, that in Germany and France the term 'exotic' primarily referred to flora and fauna - and not to people - at least until the eighteenth century, when discourses around sexuality 'exploded' as Michel Foucault (1979) demonstrated (see Rincón, 2001: 341-342). In this vein, the modern understanding of humans as biological beings coincides with the characterization of certain parts of humanity as exotic and with a growing emphasis on questions of race and of sexuality.

Gender stereotypes play a decisive role in processes of sexoticization. European discourses connected non-European women as well as femininity itself to images of wildness, sensuality and permissiveness (Weigel, 2000). ${ }^{4}$ Projections of virility and sexual potency on non-European men gave rise to fears of miscegenation, to racist topoi like the 'rape of white women', but also to envy, feelings of inferiority and sexual attraction. At the same time, colonial discourse could also, for example, feminize Asian men and de-sexualize African men by comparing them to children (Adas, 1989; Sinha, 1995). The ambivalence of such attributions is one of their main characteristics: Ideas about extra-European animalistic savagery testify to this as do images of deviant sexual encounters happening in obscure and exciting settings.

Beyond an emphasis on such intersections, the concept of body techniques can further enhance analyses of sexotic practices as it leads beyond a mere reconstruction of standardized codes. The concept points towards a wide array of behavioral patterns, from walking to dancing, from fighting to writing, from yoga course to intercourse, ranging from the everyday to the extraordinarily virtuosic. Although most of these techniques are performed in a thoughtless fashion, they are nevertheless learned and trained by following certain codes and patterns that comprise both ethical as well as aesthetical dimensions. Thus, the concept directs attention not to the body itself, whatever that may be, but to the ways in which bodies move within and among historically specific symbolic figurations, corpuses of knowledge and patterns of subjectification. Body techniques hence form a set of particularly interesting phenomena as they merge knowing and doing, thus generating inseparable links between the visceral and the social. In this vein, body techniques (Mauss, 1974: 197-220) can be seen as closely resembling the notions of habitualization (Bourdieu, 1977), disciplinization (Foucault, 1979) and materialization (Butler, 1993).

Attention to body techniques brings into view processes of optimizing bodies and bodily abilities and the circulation of different behavioral models, ranging from effortful self-training or selffashioning to unacknowledged adoption (Schildkrout, 2004: 319-344; Streng, 2013). 
Comparisons between 'civilized European' and 'barbaric non-European' ways of shaping, using and maneuvering the body actually stood at the very beginning of 'Western' debates around bodily comportment (Schüttpelz, 2010). In practical terms, world exhibitions as well as the circus or the vaudeville were for a long time the main arenas within which such arguments were settled (Hinsley, 1991; Lewerenz, 2006). Yet African American forms of supposedly erotic dancing, Asian manuals for sexual positions and 'non-Western' types of gender roles and relations carried these debates and techniques to many other spaces as well (Egan and Johnson, 2006; Karayanni, 2004; Kusser, 2013; Staszak, 2008; Urban, 2001; Willis, 2010). Performances in tourist contexts for example staged the often sexualized 'native' body as a guarantor of cultural authenticity with repercussions into the host societies and their understanding of these performances (Desmond, 1999). These dynamics were permanently generating possibilities for intercultural misunderstandings and misinterpretations on a performative level. Furthermore, they were also prone to produce failures wherever incongruities between socio-cultural expectations or personal desires and bodily capabilities arose. The collection aims at tracking some of these contacts, transfers, efforts and collapses.

Various forms of sexoticised encounters have taken place in different historical, social and cultural contexts. They surface in the intricate complexity of colonial intimacies around 1900 and have been integrated into (commercialized) sexual attractions be it in the form of Josephine Baker's famous Banana-dance or in marketing porn in reference to the ethnicity of the actor. Not least ethno-sexual encounters contribute to the significance of faraway places for the so-called age of sexual experimentation since the 1970s.

The contributions to this special issue all address intersections of the exotic and the sexual and situate them in their cultural and historical contexts. They especially highlight three aspects that were particularly prominent in modern processes of sexualization and exoticization: 1 . mobilities and migrations, 2. media and arts and 3. science and moralities.

\section{Mobilities and Migrations}

As far as actual (bodily) sexoticized encounters are concerned mobility is essential. These encounters could result from people (often, but not only North-Americans and Europeans) moving to places perceived as sexotic and their contact with people perceived as culturally (and in terms of sexoticization also physically) different. Alternatively, such encounters are made possible because people (often non-Europeans) move to places where they are perceived as sexotic frequently under the premise that there they can benefit from their sexotic image. One important framework for all kinds of sexualized exoticism and exoticised sexual relations was European imperialism, which very directly gave political significance to cultural imaginations that helped to establish, justify and maintain relations of power and (sexual) exploitation. Many of these survived into the post-colonial era and gained new social, economic and cultural significance within an increasingly globalized world, which generated both new possibilities and new limitations to sexotic practices. Contemporary transnational mobilities, be it in the context of war, tourism or migration, are heavily interwoven with this colonial heritage of sexotic stereotypes and interactions as well as with the social and economic structures related to their history (Berman, 2017).

Andrew Shield discusses such post-colonial dynamics in his contribution on everyday processes of mutual sexoticization between locals and especially Turkish and Arab migrants in Denmark in 
the late 1960s and the 1970s. He thereby not only pinpoints xenophobic depictions, mostly by heterosexual Danish men, of 'guest workers' as predators, but also analyzes the at times ambivalent positions and attributions that evolved within feminist and gay contexts when it came to the sexuality of foreigners. In this context, migrants were not only 'victims,' but they also tried to deal with and to profit from phantasms about 'oriental ars erotica.' Shield thus lucidly exposes the manifold dimensions of negative as well as of positive stereotyping in dynamics of sexoticization.

The promise and marketing of sexotic experiences has been and is furthermore most prominent in the phenomenon of sex tourism to the respective (and historically changing) hot spots of exotic and sexual longing. Allusions to the sexotic are also crucial in a more general context of tourism and tourism promotion (Pritchard and Morgan, 2000; Desmond, 1999). Beyond that, sexoticized images and relations spur the migration of mail-order brides and sex workers across national borders as well (on mostly male sex tourism: Brennan, 2004; Kempadoo, 1999; Kibicho, 2009; Seabrook, 2001; on female sex tourism: Frohlick, 2013; Jacobs, 2010; on mail order brides, see e.g. Ruenkaew, 2017; on (sex-)work related migration: Agustín, 2007; Ehrenreich and Hochschild, 2004). The sexotic therefore is integrated in manifold ways into different forms of mobility, each of which deserves close attention to its specificities and intricacies.

\section{Media and Arts}

The media does not only represent knowledge and power relations, but it also produces and reproduces, stabilizes and destabilizes both. The media is thus crucial in all practices of sexoticization and its communication. Seemingly innocent activities like writing and reading are always already intertwined with political hierarchies and global inequalities, even before one starts to consider elements such as the asymmetries between hegemonic and subaltern literatures, for example (see Bergermann, 2012: 268). Still, the question of how translations and receptions of certain texts and other media formats impact processes of sexoticization remains critical. From our point of view, (re-)translations should best be understood as historically specific variations and interpretations, highlighting the simplifications, re-significations, or inventions they entail. ${ }^{5}$ Such transfers can enhance processes of sexualizing and exoticizing the other, but they can depending on the context and on ways of reception - also subvert them (on (contemporary) literature and subversion, see Ernst, 2014: 87-182).

Generalizing assumptions about the role of the media are hence rather useless. What we need instead are concrete studies that analyze how specific genres and works impacted sexotic dynamics under specific circumstances. Art and visual culture, literature and travel reports, films and photography will all be important sources for further investigating these dynamics. At the same time, art seems itself to be sometimes inextricably linked to problematic aspects of 'traveling cultures' (Clifford, 1992: 96-116). ${ }^{6}$ The political implications of art - for example, of Primitivism in the late nineteenth century and specifically of Paul Gauguin's Tahitian paintings that sexualized and exoticized Tahitian women - are fiercely and critically discussed within art history (Duran, 2009; Solomon-Godeau, 1985; for an overview of postcolonial art history, see Karentzos, 2012: 249-266, but also Kravagna, 2016: 65-83; for empirical case studies, see Schmidt-Linsenhoff, 2010). These and many other cultural products provoke the question of how art and, more broadly, the media with its various genres and formats contributed to (de)stabilizing the hierarchy between 'the West and the rest' by means of sexoticization and how 
they produce sexotic places (Hall, 1992: 275-233). And how can we differentiate e.g. between practices of orientalizing (Said, 2003) and practices of creolizing (Glissant, 1997; Müller and Ueckmann, 2013)? What difference does it make if certain media representations prefer the use of one method over the other in order to make sense of and generate specific forms of differences and asymmetries?

Yumin Li's analysis of films from the final years of the Weimar Republic shows how the medium could both reproduce Orientalist fantasies and simultaneously highlight their artificiality. Through a close reading of two films starring the Chinese-American actress Anna Mae Wong, Li illuminates instances of appropriation, in which a sexoticized other becomes an agent, trying to strategically deploy Orientalist imagery for her own benefit, albeit within distinct constraints. As $\mathrm{Li}$ shows, Wong drew on racialized visual tropes and her biographical background to simultaneously subvert and reproduce the stereotype of the exotic woman in the films Picadilly (1929) and Shanghai Express (1932). Li's two close readings exemplify the contradictory role that media could play in both constructing and interpreting the sexotic, even in the early days of commercial film.

Quite similarly Christopher Ewing argues that gay magazines in West Germany produced and reproduced contradictory discourses of race and immigration during the so-called AIDS crisis of the 1980s. Ewing examines different gay publications across the political spectrum: from very leftists magazines like Rosa Flieder and Siegessäule to more lifestyle-orientated magazines like Du \& Ich and him applaus. He argues that within these magazines racial anxieties were still vocal in the early 1980s, but quickly overshadowed by the fear of AIDS and even more by the fears about governmental repression because of AIDS. As the 'AIDS crisis' seemed to be more and more manageable around 1990 these racial anxieties began to resurface in some, but not in all of the magazines. Ewing's article shows not a consistent but a huge variety and heterogeneity of gay magazines and their different approaches to sexuality and what we call the sexotic.

\section{Science and Moralities}

In the nineteenth and twentieth centuries, sexuality was more closely than ever connected not only to religious fears, but also to political regulations, scientific debates and aesthetic claims. It was thus embedded in dramatically changing complex constellations that impacted sexual behavior in a variety of ways, especially in western Europe and North America. Partner selection as well as sexual practices, desires, and identities were in a very broad sense shaped, promoted or sanctioned by conflicting moral values, accounts, and expectations. In these times, sexuality (in the 'West') was thus on the one hand cherished as allowing for 'individualization', 'pluralization', and 'emancipation', while it was on the other hand increasingly considered as a field that necessitated rigid medical control, state interception and police discrimination (see as a standard reference Foucault, 1998). Within moral notions of sexuality, both perspectives - sex as a source of self-fulfillment and sex as a sin, a danger or a crime - were linked to and charged against each other, allegedly in order to further not only the well-being of the individual, but also the welfare of each given society.

These moralities, we contend, were radically challenged in the nineteenth and twentieth centuries by an interest - unprecedented in its reach and intensity - in 'exotic' or 'oriental' sexuality and in 'foreign' people or bodies as an object of sexualization (see e.g. the pathbreaking studies in Gilman, 1992). Especially movements for so-called sexual reform, no matter whether they were 
driven primarily by hetero- or homosexuals, celebrated and emphatically affirmed the wide variety of sexual practices, desires, and identities they believed to find in 'Asian', 'African' or 'Mediterranean' societies and contexts (see e.g. Hirschfeld, 2006; cf. also Fuechtner, 2013). They strategically endorsed this variety as supporting their arguments within the ongoing struggles for establishing moral values, accounts and expectations that allowed for sexual plurality. Simultaneously, though, their attitudes and manners decisively contributed to the exoticization of sexuality and the sexualization of especially 'Asian', 'African' or 'Mediterranean' people and bodies. Against this background we have to contextualize historically the so-called sexual reform movements within specific moralities and at the same time critically reflect upon their role within the history of racist stereotypes and imperialist encounters.

Examining German sexual science and its dealing with 'African sexuality' between 1890 and 1930, Paul Schrader's contribution to this issue demonstrates how sexoticizations were inextricably interwoven with such negotiations of moralities and into the scientific knowledge production on sexualities. Following German colonial conquest in Africa, colonial and sexual science knowledge production interfused each other and sexual scientists helped to construct and maintain hierarchies. At the same time, discussions on female African sexuality were part of a normalizing discourse on female lust/sexuality that took place in the context of and in reference to a destabilized gender order in Europe. Schrader shows that within these sexual science discussions sexoticizations could be employed in conservative as well as emancipatory argumentations.

Along similar lines, Tamara Loos highlights the intersectional connections between sexoticization and racist as well as sexist hierarchies in her contribution on French sex reformer René Guyon (1876-1963). Guyon was a high-ranking official in the Thai government who simultaneously published his observations on Asian and African forms of sexual behavior and moralities in sexological journals. Loos particularly highlights his despise of European conventions as a sexual prison that was upheld, in Guyon's view, by resentful old spinsters. Against this model he favorably compared 'other' sexual cultures which allegedly allowed or even encouraged adolescents to engage in sexual intercourse with adult men on a voluntary basis. In his descriptions of such customs Guyon conspicuously disregards, as Loos points out, asymmetries of power along the lines of age, race and gender in his notion of consent.

All the examples thus show complex processes of constructing, instrumentalizing, adapting or appropriating sexoticizations. As with Seidl's movie some of these processes seem to build on and affirm longer Western traditions of the sexotic while others seem to run counter to established patterns and stereotypes. Schrader's and Loos' studies for example underline the projection of sexual liberality and potency on non-Western places and peoples. In contrast, Ewing's observation that anxieties expressed in racialized terms declined in face of a collective threat such as the AIDS crisis might be surprising regarding that we know many examples were the construction of racialized and sexoticized scapegoats rather proliferate in times of crisis. Reading the cases together thus also reminds us that, while we can trace the sexotic in the behavior, concepts and dreams of 'sugar mamas', scientists or sex activists alike, we always need to consider the historical context, entangle the specific, often complex power relations and pay attention to the ambiguities and contradictions that determine particular expressions of the sexotic. 


\section{Literature}

Adas M (1989) Machines as the Measure of Men: Science, Technology, and Ideologies of Western Dominance. Ithaca: Cornell University Press.

Aderinto S (2015) Journey to Work: Transnational Prostitution in Colonial British West Africa. Journal of the History of Sexuality 24(1): 99-124.

Agustín LM (2007) Sex at the Margins. Migration, Labour Markets and the Rescue Industry. London and New York: Zed Books.

Bergermann U (2012) Postkoloniale Medienwissenschaft: Mobilität und Alterität von Ab/Bildungen. In: Reuter J and Karentzos A (eds.) Schlüsselwerke der Postcolonial Studies. Wiesbaden: Springer VS, pp. 267-281.

Berman N (2017) Germans on the Kenyan Coast: Land, Charity, and Romance. Bloomington: Indiana University Press.

Bitterli U (1991) Die 'Wilden' und die 'Zivilisierten': Grundzüge einer Geistes- und Kulturgeschichte der Europäisch-Überseeischen Begegnung. Munich: C.H. Beck.

Blower BL (2011) Becoming Americans in Paris: Transatlantic Politics and Culture between the World Wars. Oxford: Oxford University Press.

Brennan D (2004) What's Love Got to Do with it? Transnational Desires and Sex Tourism in the Dominican Republic. Durham, NC: Duke University Press.

Bourdieu P (1977) Outline of a Theory of Practice. Cambridge: Cambridge University Press.

Butler J (1993) Bodies that Matter: On the Discursive Limits of Sex. New York and London: Routledge.

Clifford J (1992) Travelling Cultures. In: Grossberg L, Nelson C and Treichler P (eds) Cultural Studies. New York: Routledge, pp. 96-116.

Desmond JC (1999) Staging Tourism: Bodies on Display from Waikiki to Sea World. Chicago: Chicago University Press.

Dorfman RS (2011) A Foucauldian Analysis of Power and Prostitution: Comparing Sex Tourism and Sex Work Migration. In: Polis Journal 5.

Duran J (2009) Education and Feminist Aesthetics: Gauguin and the Exotic. Journal of Aesthetic Education 43(4): 88-95.

Eder FX (2009) Kultur der Begierde: Eine Geschichte der Sexualität. Munich: C.H. Beck.

Egan RD, Frank K and Johnson ML (2006) Flesh for Fantasy: Producing and Consuming Exotic Dance. New York: Thunder's Mouth Press.

Ehrenreich B and Hochschild AR (eds) (2004): Global woman: Nannies, maids, and sex workers in the new economy. New York: Henry Holt and Company.

Ernst T (2014) Literatur und Subversion: Politisches Schreiben in der Gegenwart. Bielefeld: transcript.

Fludernik M (ed) (2002) Der Alteritätsdiskurs des Edlen Wilden: Exotismus, Anthropologie und Zivilisationskritik am Beispiel eines europäischen Topos. Würzburg: Ergon-Verlag.

Foucault M (1978) The History of Sexuality, Volume I: The Will to Knowledge. New York: Pantheon.

Frohlick S (2013) Sexuality, Women, and Tourism: Cross-border Desires through Contemporary Travel. London and New York: Routledge.

Fuechtner V (2013) Indians, Jews, and Sex: Magnus Hirschfeld and Indian Sexology. In: Fuechtner V and Rhiel M (eds) Imagining Germany Imagining Asia: Essays in Asian-German Studies. Rochester: Camden House, pp. 111-130.

Gilman S (1992) Rasse, Sexualität und Seuche. Stereotype aus der Innenwelt der westlichen Kultur. Reinbek near Hamburg: Rowohlt.

Glissant É (1997): Poetics of Relation. Ann Arbor: University of Michigan Press.

Hall S (1992) The West and the Rest. Discourse and Power. In: Hall S and Gieben B (eds) Understanding Modern Societies, Volume 1: Formations of Modernity. Cambridge: Polity Press, pp. $275-233$.

Hilderbrand L (2013) A Suitcase Full of Vaseline, or Travels in the 1970s Gay World. Journal of the History of Sexuality 22(3): 373-402. 
Hinsley CM (1991) The World as Marketplace: Commodification of the Exotic at the World's Columbian Exposition, Chicago, 1893. In: Karp I and Levine S (eds) Exbibiting Cultures. The Poetics and Politics of Museum Display. Washington DC: Smithsonian Institution Press, pp. 344-364.

Hirschfeld M (2006) Weltreise eines Sexualforschers im Jabr 1931/32 [1933]. Frankfurt/Main: Eichborn Verlag.

Hyam R (1990): Empire and Sexuality. The British Experience. Manchester: Manchester University Press.

Jacobs J (2010) Sex, Tourism and the Postcolonial Encounter: Landscapes of Longing in Egypt. Farnham UK and Burlington VT: Ashgate.

Karayanni SS (2004) Dancing Fear and Desire: Race, Sexuality, \& Imperial Politics in Middle Eastern Dance. Waterloo, ON: Wilfrid Laurier University Press.

Karentzos A (2012) Postkoloniale Kunstgeschichte. Revisionen von Musealisierungen,

Kanonisierungen, Repräsentationen. In: Reuter J and Karentzos A (eds) Schlüsselwerke der Postcolonial Studies. Wiesbaden: Springer VS, pp. 249-266;

Kempadoo K (ed) (1999): Sun, Sex, and Gold. Tourism and Sex Work in the Carribbean. Lanham, Boulder and New York: Rowman and Littlefield Publishers.

Kibicho W (2009) Sex Tourism in Africa. Kenya's Booming Industry. Farnham UK and Burlington VT: Ashgate.

Kravagna C (2016) Postcolonial Studies. In: Gaugele E and Kastner J (eds) Critical Studies. Kulturund Sozialtheorie im Kunstfeld. Wiesbaden: Springer VS, pp. 65-83.

Kusser A (2013) Körper in Schieflage. Tanzen im Strudel des Black Atlantic um 1900. Bielefeld: transcript.

Lewerenz S (2006) Die Deutsche Afrika-Schau (1935-1940). Rassismus, Kolonialrevisionismus und Postkoloniale Auseinandersetzungen im Nationalsozialistischen Deutschland. Frankfurt/Main: Peter Lang.

Littlewood I (2002) Sultry Climates. Travel \& sex. Cambridge, MA: Da Capo Press.

Mauss M (1975) Die Techniken des Körpers. In: Mauss M (ed) Soziologie und Anthropologie, Volume 2: Gabentausch, Todesvorstellungen, Körpertechniken [1934]. Munich: Hanser Verlag, pp. 197220.

McClintock A (1995) Imperial Leather, Race Gender and Sexuality in the Colonial Contest. London and New York: Routledge.

McCall L (2005): The Complexity of Intersectionality. Signs 30(3): 1771-1800.

Müller G and Ueckmann N (eds) (2013) Kreolisierung revisited. Debatten um ein weltweites Kulturkonzept. Bielefeld: transcript.

Nagel J (2003) Race, Ethnicity and Sexuality: Intimate Intersections, Forbidden Frontiers. Oxford: Oxford University Press.

Popp RK (2010) Domesticating Vacations: Gender, Travel, and Consumption in Post-war Magazines. Journalism History 36(3): 126-137.

Pritchard A and Morgan NJ (2000) Privileging the Male Gaze: Gendered Tourism Landscapes. Annals of Tourism Research 27(4): 884-905.

Puar J (2011) 'I would rather be a cyborg than a goddess': Intersectionality, Assemblage, and Affective Politics. transversal 8: inventions | inventionen. Available at: http://eipcp.net/transversal/0811/puar/en (accessed: 30 December 2017).

Puar J (2007) Terrorist Assemblages: Homonationalism in Queer Times. Durham, NC: Duke University Press.

Rincón C (2001 'Exotisch/Exotismus'. In: Barck K (ed) Ästhetische Grundbegriffe, Volume 2: Dekadent, Grotesk. Stuttgart and Weimar: Verlag J.B. Metzler, pp. 338-365.

Ruenkaew P (2017) Victims of Traffic in Women, Marriage Migrants, and Community Formation: a History of Migration of Thai Women to Germany. In: Cho JM und McGetchin DT (eds) Gendered Encounters between Germany and Asia: Transnational Perspectives since 1800. Cham: Springer International Publishing, pp. 253-273. 
Said EW (2003) Orientalism [1978]. New York: Vintage Books.

Schildkrout E (2004) Inscribing the Body. Annual Review of Anthropology 33: 319-344.

Schmidt-Linsenhoff V (2010) Ästhetik der Differenæ: Postkoloniale Perspektiven vom 16. bis 21. Jabrbundert. 15 Fallstudien, Volume 1: Texte, Volume 2: Abbildungen. Marburg: Jonas Verlag.

Schüttpelz, Erhard (2010): Körpertechniken. Zeitschrift für Medien und Kulturforschung 2(1): 101-120.

Sinha M (1995) Colonial Masculinity: The 'Manly Englishman' and the 'Effeminate Bengali' in the Late Nineteenth Century. Manchester: Manchester University Press.

Staszak JF (2008) Exotic Dance, Erotic Dance: Displaying the Other's Body from the 18th to the 20th Century. Annales de Géographie 2-3 (660-661).

Streng M (2013) Kampf - Kunst - Körper: Zum Verhältnis von Körper- und Gewaltgeschichte in 'fernöstlichen Kampftechniken' in (West-)Deutschland (1920er bis 1980er Jahre). body politics 1(2): 231-258.

Schülting S (1997) Wilde Frauen, fremde Welten. Kolonisierungsgeschichten aus Amerika. Reinbek near Hamburg: Rowohlt.

Seabrook J (2001) Travels in the Skin Trade. Tourism and the Sex industry. London: Pluto Press.

Solomon-Godeau A (1985) Going Native: Paul Gauguin and the Invention of Primitivist Modernism. In: Broude N and Garrard M (eds) The Expanded Discourse: Feminism and Art History. New York: Harper Collins.

Stoler AL (1995) Race and the Education of Desire. Foucaults History of Sexuality and the Colonial Order of Things. Durham: Duke University Press.

Urban HB (2001) The Omnipotent Oom. Tantra and Its Impact on Modern Western Esotericism. Esoterica 3: 218-259.

Weigel S (2000) Die nahe Fremde - das Territorium des 'Weiblichen': Zum Verhältnis von 'Wilden' und 'Frauen' im Diskurs der Aufklärung. In: Koebner T and Pickerodt G (eds): Die Andere Welt. Studien zum Exotismus. Berlin: Philo, pp. 171-199.

Willis D (ed) (2010) Black Venus 2010: They Called Her 'Hottentot'. Philadelphia: Temple University Press.

Yegenoglu M (1998) Colonial Fantasies: Towards a Feminist Reading of Orientalism. Cambridge: Cambridge University Press.

\footnotetext{
${ }^{1}$ Dorfman (2011) has pointed out the similarity of sex tourism and sex work migration.

${ }^{2}$ We understand sexuality as a thoroughly historical phenomenon and sex as always embedded in and shaped by social and cultural contexts.

3 There is for example also a tradition in US tourism to imagine Europe, France in particular, as a sexualized space (see e.g. Blower, 2011: 140-46; Popp, 2010: 128).

4 These processes can be traced back as far as the sixteenth century.

5 'One Thousand and One Nights', the famous collection of West and South Asian stories, was e.g. first translated into French and English at the beginning of the eighteenth century. These translations were then again translated into German not before the nineteenth century.

${ }^{6}$ Hilderbrand (2013: 376) sticks to a crucial point when he emphasizes that gay magazines in the US also constituted a 'homogenized national gay culture' through presenting their readers 'the concept of different (though often familiar) local gay scenes in each city or foreign country'.
} 